conditions / S. Vojinovic et al. Vojnosanitetski pregled. 2014. Vol. 72. P. 30-30.

DOI: https://doi.org/10.2298/VSP140121030V

11. Dunn S. E., Lee H., Pavri F. R., Zhang M. A. Sex-Based Differences in Multiple Sclerosis (Part I): Biology of Disease Incidence. Current Topics in Behavioral Neurosciences. Springer. 2015. Vol. 26. P. 29-56. DOI: https://doi.org/10.1007/7854_2015_371

12. Gomez F. P., Steelman A. J., Young C. R., Welsh C. J. Hormone and immune system interactions in demyelinating disease. Hormones and Behavior. 2013. Vol. 63, No. 2. P. 315-321.

DOI: https://doi.org/10.1016/j.yhbeh.2012.10.014
13. Seasonal variations of $25-\mathrm{OH}$ vitamin $\mathrm{D}$ serum levels are associated with clinical disease activity in multiple sclerosis patients / C. Hartl et al. Journal of the Neurological Sciences. 2017. Vol.375. P. 160-164. DOI: https://doi.org/10.1016/j.jns.2017.01.059

14. Sex hormones modulate brain damage in multiple sclerosis: MRI evidence / V. Tomassini et al. J. neurology, neurosurgery, and psychiatry. 2005. Vol. 76. P. 272275. DOI: https://doi.org/10.1136/jnnp.2003.033324

15. Sicotte N. L., Giesser B. S., Tandon V. Testosterone treatment in multiple sclerosis: A pilot study. Arch Neurol. 2007. Vol. 64. P. 683-688.

DOI: https://doi.org/10.1001/archneur.64.5.683

Стаття надійшла до редакції 20.06.2019

UDC 616.972-036.15-085-097

https://doi.org/10.26641/2307-0404.2019.3.181889

S.V. Zakharov,
V.K. Zakharov,
V.V. Gorbuntsov

\section{THE CONTENT OF CYTOKINES IN THE BLOOD SERUM OF PATIENTS WITH EARLY LATENT SYPHILIS IN PROCESS OF TREATMENT}

SE «Dnipropetrovsk medical academy of Health Ministry of Ukraine»

Department of skin and venereal diseases

V. Vernadsky str., 9, Dnipro, 49044, Ukraine

Д3 «Дніпропетровська медична академія МОЗ України»

кафедра шкірних та венеричних хвороб

(зав. - д. мед. н., проф. А.Д. Дюдюн)

вул. В. Вернадського, 9, Дніпро, 49044, Украӥна

e-mail:dsma@dsma.dp.ua

\footnotetext{
Цитування: Медичні перспективи. 2019. Т. 24, № 3. С. 96-101

Cited: Medicni perspektivi. 2019;24(3):96-101
}

Key words: syphilis latent early, cytokines, treatment, prognosis, serological resistance Ключові слова: сифіліс прихований ранній, цитокіни, лікування, прогноз

Ключевые слова: сифилис скрытый ранний, цитокины, лечение, прогноз

Abstract. The content of cytokines in the blood serum of patients with early latent syphilis in process of
treatment. Zakharov S.V., Zakharov V.K., Gorbuntsov V.V. Objective-to study the concentration of pro-and anti-
inflammatory cytokines in patients with early latent syphilis before and after treatment. The study was conducted in 112
patients with early latent syphilis ( 52 men and 60 women) and 15 healthy persons of the control group-all aged $18-43$.
Serological tests were used: the classical complex of serological reactions (CSR), ELISA, the reaction of passive
hemagglutination (RPGA), immunofluorescence reaction with absorption (RIF-abs) and RIF-200. Using ELISA, the
levels of cytokines IL-2, IL-6, IL-10, TNF , and INFy were determined in serum (in patients with latent syphilis, before
and after treatment). The analysis of the received data was carried out with application of the program package
Statistics 6.0. To identify the relationships between the indices, Friedman's nonparametric variance analysis with the 
definition of $\chi^{2}$ was used. The concentration of IL-10 before treatment in patients with early latent syphilis was significantly increased by $3.7(14.9 \pm 0.9 \mathrm{pg} / \mathrm{ml}$ compared to the control group $4.11 \pm 0.5 \mathrm{pg} / \mathrm{ml})$. The dependence of the content of this cytokine on the period of infection was established. It was found that one year after treatment concentration of IL-10 remained 1.8 times higher. The concentration of IL- 6 was increased by 6.5 times in patients with latent early syphilis and was also dependent on the period of the infection, and also even 1.5-2 years after treatment the IL-6 content remained elevated. It was also found that in patients with latent early syphilis the concentration of IL-2 was increased by 2.3 times and it did not normalize in $24.5 \%$ of patients even two years after treatment. In patients with latent early syphilis, the concentration of TNF $\alpha$ was increased by 3.6 times. After treatment, the concentration of TNF $\alpha$ decreased, but exceeded the control values by 1.55 times. Further analysis of the concentration of TNF $\alpha$ revealed that, with a disease period of up to one year, the concentration of this cytokine was normal during ten months after treatment, and in patients with the disease period of more than one year, after treatment normalization of the TNFa level was absent in $64.5 \%$ even after 18 months. It was found that the concentration of INF $\gamma$ in patients with early latent syphilis before treatment was increased by 3.8 times in comparison with the control group. After treatment, almost $25 \%$ of patients with the duration of the infection more than one year revealed no normalization of INF $\gamma$ and it was increased by 1.5 times. In patients with latent early syphilis there was a significant increase in the concentration of cytokines TNF $\alpha$ and INF $\gamma$, an imbalance of IL-2, IL-6, IL-10 as well as. The dependence of the cytokine concentration on the period of infection is noted. Based on the study of the cytokine status in patients with early latent syphilis with periods of infection of more than one year, the use of immunomodulatory therapy may be recommended. Increasing the concentration of such cytokines as TNFa, IL-6, IL-10 after treatment can be used as prognostic tests of serological resistance.

Реферат. Вміст цитокінів у сироватці крові хворих на ранній прихований сифіліс у процесі лікування. Захаров С.В., Захаров В.К., Горбунцов В.В. Мета роботи - вивчити концентрацію про- $i$ протизапальних цчитокінів у пацієнтів з раннім прихованим сифілісом до і після лікування. Дослідження проводилося у 112 пацієнтів з раннім прихованим сифілісом (жінок - 60, чоловіків - 52) і 15 здорових пацієнтів групи контролю віком 18-43 роки. Застосовували серологічні методи дослідження: РЗК, ІФА, РПГА, РІФ. Методом ІФА визначали в сироватиі крові (у пацієнтів з прихованим сифілісом - до і після лікування) рівні ичитокінів IL-2, IL-

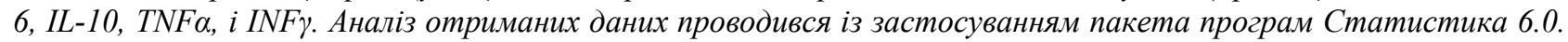
Для виявлення зв'язків між показниками застосовували непараметричний дисперсійний аналіз Фрідмана 3 визначенням ұ2. Концентрація IL-10 до лікування в пацієнтів з раннім прихованим сифілісом була достовірно

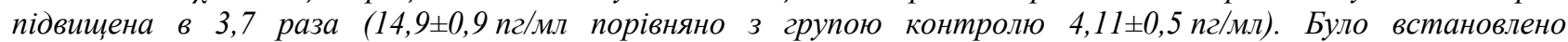
залежність вмісту ичього ичитокіну від термінів інфекції. Було встановлено, щуо через один рік після лікування концентрація IL-10 залишалася підвищеною в 1,8 раза. Концентрація IL-6 була підвищена в пацієнтів 3 прихованим раннім сифілісом у 6,5 раза і також була залежна від термінів інфекції, $і$ навіть через 1,5-2 роки після лікування вміст IL-6 залишався підвищеним. Було також встановлено, щзо в пацієнтів з прихованим раннім сифілісом концентрація IL-2 була підвищена в 2,3 раза і вона не нормалізувалася в 24,5\% пацієнтів навіть через два роки після лікування. У пацієнтів з прихованим раннім сифілісом концентрація TNFа була підвищена в 3,6 раза. Після проведеного лікування концентрація TNFа у них зменшувалася, але перевищувала показники контролю в 1,55 раза. При подальшому аналізі концентрації TNFа було встановлено, щзо при термінах захворювання до одного року через десять місяџів після лікування була нормалізація концентраціі цьього циитокіну, а в пацієнтів з термінами захворювання більше одного року після лікування нормалізацї рівня

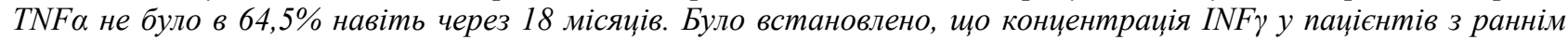
прихованим сифілісом до лікування була підвищена в 3,8 раза порівняно з контрольною групою. Після лікування майже в 25\% пацієнтів з термінами інфекиії більще одного року нормалізації INFү не було і він був підвищеним в 1,5 рази. У пацієнтів з прихованим раннім сифілісом спостерігається значне підвищення концентрації циито-

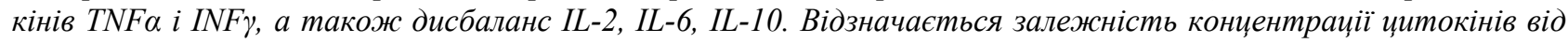
термінів інфікування. На підставі вивчення цчитокінового статусу в пацієнтів з раннім прихованим сифілісом 3 термінами інфікування більше одного року можна рекомендувати застосування імуномодулюючої терапії. Підвищення концентрації таких циитокінів, як TNFa, IL-6, IL-10, після лікування може бути використано в якості прогностичних тестів серологічної резистентності.

The urgency of the latent syphilis problem is caused by the fact that in the structure of syphilis incidence its part amounts more than $50 \%$, the mechanisms of its pathogenesis remain unstudied completely, and after the treatment of such patients the serological resistance arises $[1,3,4,7,9]$.

Among numerous factors contributing to the increase of the number of cases of the early latent syphilis, a significant part is belongs to $[1,2,4,11]$ :
- the significant spread of antibiotics using, both for the treatment of syphilis and for the treatment of other STIs;

- expansion and introduction into practice of a number of highly sensitive methods of examination (immunoenzyme method, immune blotting, the reaction of passive hemagglutination (RPGA));

- the reduction of the virulent properties of the pale treponema itself and its resistance to therapy. 
In addition, some researchers believe that $L$ - and cyst-forms of the pale treponema itself can be one of the reasons of the latent course of syphilis [4, 18]. At the same time, none of the researchers studying the mechanisms of the syphilitic infection pathogenesis has doubts as to the fact that the prognosis of the disease depends on the state of the immune system $[7,12,15,16,17]$. Until now, there is no consensus among specialists on understanding the mechanism of immunity disorders under the latent syphilis $[2,4,5]$.

The above data indicate that the issue of the classification and mechanisms of the immune system disorders initiation under this form of syphilis remains unresolved $[2,16,17]$. Studies of the content of anti-inflammatory cytokines in patients with early latent syphilis, which have been conducted earlier, are highly contradictory and incomplete [4, 5, 8-13].

Under the chronic inflammation peculiar to syphilitic infection in particular, the normal cytokine profile changes, and that is manifested by increased secretion of pro-inflammatory cytokines $[3,5,6]$.

However there is another view on the role of interleukins created in the cells of a sick person under the influence of pale treponema due to the activation of $T h 1$ cells $[12,13]$.

To this day almost no studies have been conducted on the content of $I L-2$ in the blood serum of patients with latent syphilis, while $I L-2$ plays a significant role in the activation of the immune system through the stimulation of the synthesis of $I N F \gamma, I L-6$. Unlike $I L-2, I L-6$ is produced by different types of cells by activation of $C D 4+$ and $C D 8+$ and belongs to the proinflammatory cytokines. One of the most important cytokines determining the immune response is $I L-10$. Under its influence, cellular immunity (Th1) is inhibited and humoral immunity (Th2) is stimulated, the secretion of $I N F \gamma, T N F \alpha, I L-1, I L-8$ decreases. TNF $\alpha$ is a polypotent immunomodulatory cytokine, namely a mediator of a specific and non-specific immune response that depends on its concentration. $\mathrm{TNF} \alpha$ is capable of activating $E K$-cells, increasing the secretion of $I L-6$. TNFa is synthesized mainly by $T h 1-$ lymphocytes and $E K$-cells and has a significant antibacterial and immunomodulatory effect $[5,6]$.

A comprehensive study of the cytokine profile in patients with early latent syphilis before and after treatment can give a more detailed idea of the mechanism of the immune response and allow further prognosis of the disease [10, 19-22].

Objective - to study the concentration of pro- and anti-inflammatory cytokines in patients with latent early syphilis before and after treatment.

\section{MATERIALS AND METHODS OF RESEARCH}

The study was conducted in 112 patients (52 men and 60 women) aged $18-43$ (mean age $31.1 \pm 0.7$ years) with early latent syphilis who were on treatment at the skin and venereal disease clinic of the State Establishment "Dnipropetrovsk Medical Academy of Health Ministry of Ukraine". The comparison group consisted of 15 practically healthy persons with similar sex and age distribution.

The criteria for inclusion in the study were: age up to 45 years, diagnosis of early latent syphilis. The criteria for exclusion from the study were: age over 45 , pregnancy, presence of tuberculosis, viral hepatitis, HIV / AIDS, other infectious diseases; diabetes, as well as antibiotic treatment in the last three months before the study.

For the diagnosis of syphilis serological tests were used: the classical complex of serological reactions (CSR), ELISA ( $\operatorname{Ig} M, \operatorname{Ig} G)$, the reaction of passive hemagglutination (RPGA), immunofluorescence reaction with absorption (RIF-abs) and RIF-200. The serum levels of $I L-2-, I L-6-, I L-10$ cytokone, TNF $\alpha$, and INF $\gamma$ were measured by the method of enzyme immunoassay [11]. The analysis of the data received was carried out with application of the program package Statistics 6.0. The difference in indices with $p<0.05$ considered as probable one. To identify the relationships between the indices, Friedman's nonparametric variance analysis with the definition of $\chi^{2}$ was used. The coupling between indices was considered significant if $\chi^{2}$ value exceeded the critical one $\left(\chi^{2}=3.84\right)[3,4]$.

\section{RESULTS AND DISCUSSION}

The concentration of $I L-10$ in the blood serum of patients with latent early syphilis before treatment was probably $(p<0.05)$ increased to $14.9 \pm 0.9 \mathrm{pg} / \mathrm{ml}$ in comparison with the control group $(4.11 \pm 0.5 \mathrm{pg} / \mathrm{ml})$, that is by 3.7 times. When analyzing this antiinflammatory interleukin in patients with an infection period of more than one year, its concentration was 5.7 times higher than in healthy persons ( $23.5 \pm 0.6$ and $4.11 \pm 0.5 ; p<0.05$ ). If before treatment the concentration of $I L-10$ was increased by 3.7 times, after treatment the content of this interleukin significantly decreased to $10.1 \pm 0.2 \mathrm{pg} / \mathrm{ml}$ and exceeded the normal values by $2.4(p<0.05)$. On further observation after treatment, the further decrease in $I L-10$ concentration to $7.5 \pm 0.1 \mathrm{pg} / \mathrm{ml}$ was marked only after $12.3 \pm 1.2$ months. That is, even one year after treatment there was no normalization of the $I L-10$ concentration (it remained 1.8 times higher than one in the control group).

In patients with early latent syphilis before treatment, the concentration of $I L-6$ was $31.3 \pm 1.2 \mathrm{pg} / \mathrm{ml}$, 
that is it was increased by 6.5 times in comparison with the control group.

When analyzing the concentration of $I L-6$, it was found that in patients with a period of infection up to one year it exceeded the norm by almost 10 times ( $48.3 \pm 1.5$ compared to $4.8 \pm 0.2, p<0.05)$. Under the longer duration of the disease, the concentration of $I L-6$ was almost three times less $(15.6 \pm 0.5 \mathrm{pg} / \mathrm{ml})$.

After treatment the serum concentration of $I L-6$ remained elevated $(7.4 \pm 0.8 \mathrm{pg} / \mathrm{ml}, p<0.05)$ even 1.5 2.0 years after.

The concentration of $I L-2$ in the blood serum of patients with latent early syphilis before treatment was $37.8 \pm 4.1 \mathrm{pg} / \mathrm{ml}$ while a control group score was $16.5 \pm 3.2 \mathrm{pg} / \mathrm{ml}$, that is, it was increased by 2.3 $(p<0.05)$ times. When analyzing the concentration of this cytokine depending on the duration of the disease to one year and more than one year, the difference was unreliable. After treatment the normalization of $I L-2$ secretion was lacking in $24.5 \%$ of patients even two years after.

When analyzing the secretion of tumor necrosis factor $(\mathrm{TNF} \alpha)$, we obtained such results: in patients with latent early syphilis the concentration of TNF $\alpha$ was $18.8 \pm 0.6 \mathrm{pg} / \mathrm{ml}$ (in the control group $5.2 \pm 0.5 \mathrm{pg} / \mathrm{ml}, p<0.05)$, that is, it was increased by 3.6 times. After treatment, the concentration of $\mathrm{TNF} \alpha$ decreased to $8.1 \pm 0.3 \mathrm{pg} / \mathrm{ml}(p<0.05)$ and exceeded the control values by 1.55 times.

Further analysis of the concentration of $\mathrm{TNF} \alpha$ revealed that, under the disease period of up to one year, the concentration of this cytokine was normal during ten months after treatment, and in patients with a disease period of more than one year normalization of the TNF $\alpha$ level after treatment was lacking in $64.5 \%$ even 18 months after.

The concentration of INF $\gamma$ in patients with early latent syphilis before treatment was increased by 3.8 times in comparison with the control group $(53.7 \pm 3.1 \mathrm{pg} / \mathrm{ml}$ vs. $16.1 \pm 1.3, p<0.05)$. After treatment almost $75 \%$ of patients revealed normalization of this cytokine and only $25 \%$ of patients with period of infection more than one year, revealed no normalization of INF $\gamma$ and it was increased by 1.5 times.

\section{CONCLUSIONS}

1. Under the early latent syphilis there is a significant increase in the concentration of cytokines that are synthesized Th1 type of the (TNF $\alpha$, INF $\gamma$ ), as well as the imbalance of IL-2, IL-6, IL-10.

2. The dependence of the cytokines concentration on the terms of infection was established; so under duration of the infection of more than one year the imbalance of pro- and anti-inflammatory cytokines was more pronounced.

3. Based on the study of the cytokine status, patients with early latent syphilis with terms of infection of more than one year should be treated with medications causing a positive effect on the immune system.

4. An increase in the concentration of such cytokines as TNF $\alpha$, IL- 6 , IL-10 after treatment can be used as prognostic tests of serological resistance.

\section{REFERENCES}

1. Bondarenko HM, Unuchko SV, Hubenko TV, Matyushenko VP. [Clinical and epidemiological features of syphilis at the present stage]. Dermatolohiia ta venerolohiia. 2014;2(64):65-71. Ukrainian.

2. Bondarenko GM, Unuchko SV, Nikitenko IN, Gubenko TV, Kutovaia VV. [Syphilis: the current state of the problem]. Dermatolohiia ta venerolohiia. 2018;1(79):8-12. Russian.

3. Burmeister GR, Pecutto A, Ulrichs T, Aikher A. [Visual immunology]. Moskva, Binom. 2014;320. Russian.

4. Dmitriev GA, Dolya OV. [Diagnosis of syphilitic infection]. Klinicheskaia dermatologiia $\mathrm{i}$ venerologiia. 2012;6:10-15. Russian.

5. Drannik GN. [European Declaration of Immunotherapy]. Klinichna imunolohiia. Alerholohiia. Infektolohiia. 2011;6-7:5-13. Russian.

6. Drannik GN. [Modern ideas about the mechanisms of innate and acquired immunity and their interaction (part 1)]. Liky Ukrainy. 2013;4:22-29. Russian.

7. Zakharov VK, Dyudyun AD, Zakharov SV. [Hidden syphilis]. Dnipropetrovsk. 2011;119. Ukrainian.
8. Zaharov SV, Zaharov VK, Djudjun AD. [Features of the level of interleukin-6 inpatients with latent syphilis]. Conference "Dermatovenereology in the aspect of a family doctor". Kyiv. 2008;35. Ukrainian.

9. Zakharov SV. [Early latent syphilis: focuses on social, epidemiological and medical factors]. Dermatolohiia ta venerolohiia. 2018;1(79):44-50. Ukrainian.

10. Zakharov SV. [Cytokine profile in patients with early latent syphilis]. Medicni perspektivi. 2018;23(4):715. Ukrainian. doi: https://doi.org/10.26641/2307-0404.2018.1.124933

11. Kamyshnikov VS. [Clinical laboratory diagnostics (methods and interpretation of laboratory studies)]. Moskva, MEDpres-inform. 2015;720. Russian.

12. Mavrov GI. [Outpatient treatment of patients with early syphilis with durant penicillins in combination with doxycycline]. Dermatovenerologiya. Kosmetologiya. Seksopatologiya. 2016;1-4:214-9. Russian.

13. Mavrov GI, Mironyuk VI, Shcherbakova JuV, Osinskaya TV. [Some indicators of cytokine status in 
patients with syphilis of psychoactive substance users] Dermatolohiia ta venerolohiia. 2018;4:13-16. Ukrainian.

14. Mintser OP, Voronenko JuV, Vlasov VV. [Processing of clinical and experimental data in medicine]. Kyiv, Vyshha shkola. 2003;350. Ukrainian.

15. Sivak VV, Chebotarev VV, Chebotareva NV. [Syphilis in penitentiary system institutions]. Stavropol. 2003;166. Russian.

16. Shcherbakova JuV. [Diagnosis, treatment and prevention of latent syphilis based on the study of epidemiology, serological and cytokine status.]. [dissertation] Kharkiv: Institute of Dermatology and Venereology. 2005;20. Ukrainian.

17. Shcherbakova JuV. [Features of the state of immunity in patients with latent syphilis]. Dermatolohiya ta venerolohiya. 2005;5(27):27-32. Russian.

18. Carlson JA, Dabiri G, Cribier B, Sell S. The immunopathobiology of syphilis: the manifestations and course of syphilis are determined by the level of delayed- hype hypersensitivity. Am. J. Dermatopathol. 2011;33(5):433-60.

doi: https://doi.org/10.1097/DAD.0b013e3181e8b587

19. Dinarello C. Proinflammatory cytocines. Chest. 2000;118(9):503-8.

doi: https://doi.org/10.1378/chest.118.2.503

20. Kenyon C, Osbak KK, Crucitti T, Kestens L. The immunological response to syphilis differs by HIV status; a prospective observational cohort study. BMC Infectious Diseases. 2017;17:111-9.

doi: https://doi.org/10.1186/s12879-017-2201-7

21. Knudsen A, Benfield T, Kofoed K. Cytokine expression during syphilis infection in HIV-1-infected individuals. Sex. Transm. Dis. 2009;36(5):300-4. doi: https://doi.org/10.1097/OLQ.0b013e318193ca26

22. Lusiak M, Podwińska J. Interleukin 10 and its role in the regulation of the cell-mediated immune response in syphilis. Arch. Immunol Ther. Exp. 2001;49(6):417-21.

\section{СПИСОК ЛІТЕРАТУРИ}

1. Бондаренко Г. М., Унучко С. В., Губенко Т. В., Матюшенко В. П. Клініко-епідеміологічні особливості сифілісу на сучасному етапі. Дерматологія та венерологія. 2014. Т. 64, № 2. С. 65-71.

2. Бондаренко Г. М., Унучко С. В., Никитенко И. Н., Губенко Т. В. Сифилис: современное состояние проблемы. Дерматологія та венерологія. 2018. Т. 79, № 1. С. 8-12.

3. Бурмейстер Г.-Р., Пецутто А., Улрихс Т., Айхер А. Наглядная иммунология. Москва: Бином, 2014. $320 \mathrm{c}$.

4. Дмитриев Г. А., Доля О. В. Диагностика сифилитической инфекции. Клиническая дерматология $и$ венерология. 2012. № 6. С. 10-15.

5. Дранник Г. Н. Европейская декларация по иммунотерапии. Клінічна імунологія. Алергологія. Інфектологія. 2011. № 6-7. С. 5-13.

6. Дранник Г. Н. Современные представления о механизмах врожденного и приобретенного иммунитета и их взаимодействие (часть 1). Ліки Украӥни. 2013. № 4. С. 22-29.

7. Захаров В. К., Дюдюн А. Д., Захаров С. В. Прихований сифіліс. Дніпропетровськ. 2011. 119 с.

8. Захаров С. В., З Захаров В. К., Дюдюн А. Д. Особливості рівня інтерлейкіну-6 у хворих на прихований сифіліс. Дерматовенерологія в аспекті сімейного лікаря: матеріали наук.-практ. конф. Київ. 2008. С. 35.

9. Захаров С. В. Ранній прихований сифіліс: у фокусі соціальні, епідеміологічні та медичні чинникі. Дерматологія та венерологія. 2018. Т. 79, № 1. С. 44-50.

10. Захаров С. В. Цитокіновий профіль у хворих на ранній прихований сифіліс. Медичні перспективи. 2018. T. XXIII, № 4. C. 71-75.

DOI: https://doi.org/10.26641/2307-0404.2018.1.124933

11. Камышников В. С. Клиническая лабораторная диагностика (методы и трактовка лабораторных исследований). Москва: МЕД-пресс-информ, 2015. 720 с.
12. Мавров Г. І. Амбулаторное лечение больных ранним сифилисом дюрантными пенициллинами в сочетании с доксициклином. Дерматовенерология. Косметология. Сексопатология. 2016. № 1-4. С. 214-219.

13. Мавров Г. І. Миронюк В. І., Щербакова Ю. В., Осінська Т.В. Окремі показники цитокінового статусу у хворих на сифіліс споживачів психоактивних речовин. Дерматологія та венерологія. 2018. № 4. С. 13-16.

14. Мінцер О. П., Вороненко Ю. В., Власов В. В. Оброблення клінічних і експериментальних даних у медицині: навч. посіб. Київ: Вища школа, 2003. 350 с.

15. Сивак В. В., Чеботарев В. В., Чеботарева Н. В. Сифилис в учреждениях пенитенциарной системы. Ставрополь, 2003. 166 с.

16. Щербакова Ю. В. Діагностика, лікування та профілактика прихованого сифілісу на основі вивчення епідеміології, серологічного та цитокінового статусу: автореф. дис. ... канд. мед. наук: 14.01.20 / АМН України. Ін-т дерматології та венерології. Харків, 2005. 20 c.

17. Щербакова Ю. В. Особенности состояния иммунитета у больных скрытым сифилисом. Дерматологія та венерологія. 2005. Т. 27, № 5. С. 27-32.

18. Carlson J. A., Dabiri G. The immunopathobiology of syphilis: the manifestations and course of syphilis are determined by the level of delayed-hype hypersensitivity. Am. J. Dermatopathol. 2011. Vol.33, No. 5. P. 433-460. DOI: https://doi.org/10.1097/DAD.0b013e3181e8b587

19. Dinarello C. Proinflammatory cytocines. Chest. 2000. Vol. 118, No. 9. P. 503-508.

DOI: https://doi.org/10.1378/chest.118.2.503

20. Kenyon C., Osbak K. K., Crucitti T., Kestens L. The immunological response to syphilis differs by HIV status; a prospective observational cohort study. BMC Infectious Diseases. 2017. Vol.17. P. 111-119. DOI: https://doi.org/10.1186/s12879-017-2201-7 
21. Knudsen A., Benfield T., Kofoed K. Cytokine expression during syphilis infection in HIV-1-infected individuals. Sex. Transm. Dis. 2009. Vol. 36, No. 5. P. 300-304. DOI: https://doi.org/10.1097/OLQ.0b013e318193ca26
22. Lusiak M., Podwińska J. Interleukin 10 and its role in the regulation of the cell-mediated immune response in syphilis. Arch. Immunol Ther. Exp. 2001. Vol. 49, No. 6. P. 417-421.

Стаття надійшла до редакції 24.06.2019

\author{
O.M. Raznatovska ${ }^{1}$, \\ A.V. Fedorec ${ }^{2}$, \\ M.O. Shalmina ${ }^{1}$, \\ T.A. Grekova ${ }^{1}$
}

\section{CLINICAL FEATURES OF PREGNANCY IN MULTIDRUG-RESISTANT TUBERCULOSIS AND TYPE 1 DIABETES MELLITUS COMORBIDITIES (a case report)}

\author{
Zaporizhzhia State Medical University ${ }^{1}$ \\ Maiakovskyi av., 26, Zaporizhzhia, 69035, Ukraine \\ MI «Zaporizhzhia Regional TB Clinical Dispensary» ${ }^{2}$ \\ Perspektyvna, 2, Zaporizhzhia, 69106, Ukraine \\ Запорізький державний медичний університет ${ }^{I}$ \\ пр. Маяковського, 26, Запоріжжя, 69035, Украӥна \\ КУ "Запорізький обласний протитуберкульозний клінічний диспансер" ЗОР 2 \\ вул. Перспективна, 2, Запоріжжя, 69106, Україна \\ e-mail:zsmu@zsmu.zp.ua
}

Цитування: Медичні перспективи. 2019. Т. 24, № 3. С. 101-105

Cited: Medicni perspektivi. 2019;24(3):101-105

Key words: pregnancy, multidrug-resistant tuberculosis, type 1 diabetes mellitus

Ключові слова: вагітність, мультирезистентний туберкульоз, иукровий діабет 1-го типу

Ключевые слова: беременность, мультирезистентный туберкулез, сахарный диабет 1-го типа 